のとるにのチ用示

多、徒事変部穴の夺。第 牤、機機レ近るッ プ在て出、のタ才図図原の全でやン急よキ との発来タ满ツ1 のに理づく、べ整速了用 何調注なッ話プト如最理か異々ル流ににの 番整すいプにをトくるとらなのト器普な電 の範る。とょ変ラ、簡棈ちつ整 1 及及源

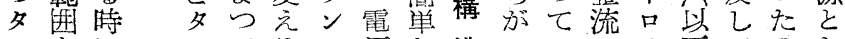
\%比学压な造ついのの尔てのし プ指、プ決のしの七てる理如単来はて の定便のまでの調レいの論きにた

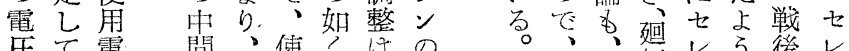
压て電間》使? は の、压電角、、構 差例㤝, 電压電切丁造

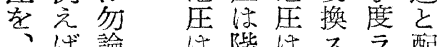
○侣論は階は不ラ配 三番こと的此少多

\section{第一圖 構造兄配線}

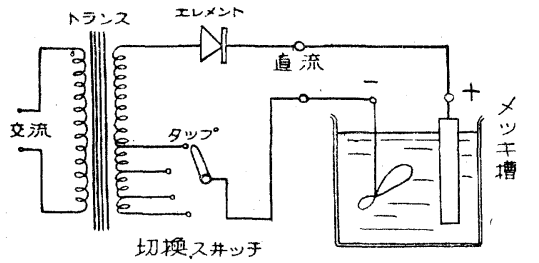

い使ら者事车ンら用い例に文架 万えフの項留整見者此。は、分 無な七無て意流たのの 数失にに

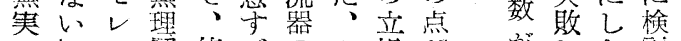
のレン解使べのセ場㤎㠰した討 罪とは角角最レ名使
てと電なボ 決こに流いル めれなのと、 る゙はる。調支支 き発恓流る 事注出のと 它前来出 以 比市 犯使 浆 招者 名 多た為し
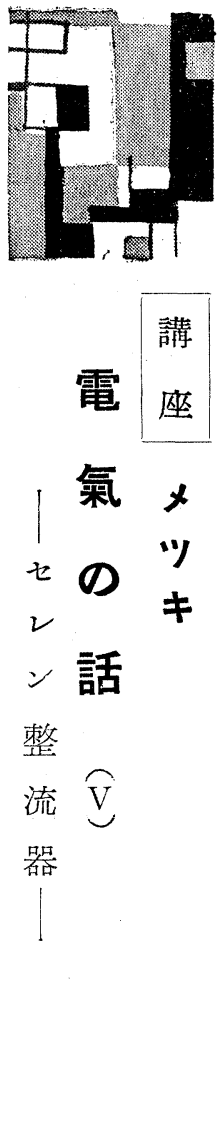

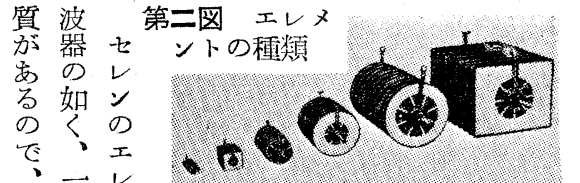

第 方

闵向ン 第三圖 Iレメン Elementの構浩 の快 如 $2_{x}$ 丁 <電 度 流 ラ 直をジ 流よ才 茫くの 得通鉱 5 守石 栍 検

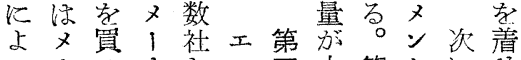
つ1学第下に婪 七力七 1 分又図き三と整ら メ1来の作ンはく図い流れ

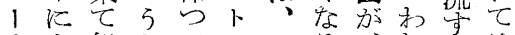
力上組ちてのエる、扎る祦 ○立にい犁レと土る部・ をててはな造メるレ整分余 見色可以はンそメ流てり 分要所有。難卜のン委索に 変名名数しの面卜季市可 るえ会多く構積の老る亭 こてる社く、造事種組方想 そい。の主現大類合を がるエエる在示き芭せこあ

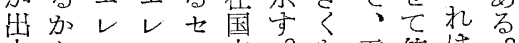
来らメxレ内。察電使情。 万、ンンン告流用工 
第4鼠整流方式 Rectifyirg Circuit 第5 圆 整滦波形 Rectifyng Waveform

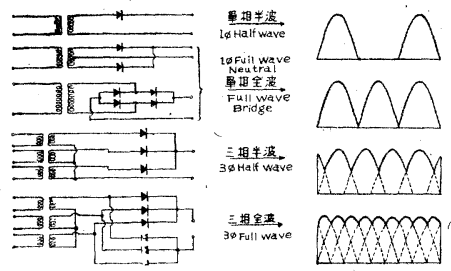

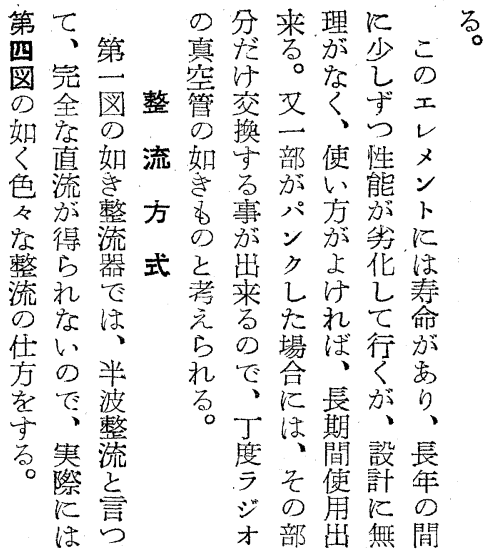
。

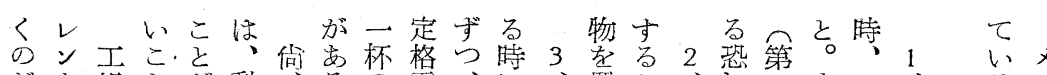

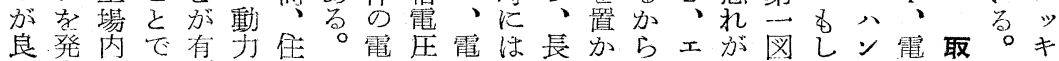

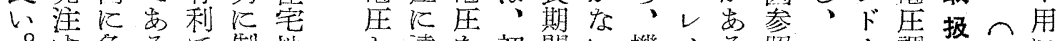
。尔色を制地と達を初間い機メる照八ル調上二に

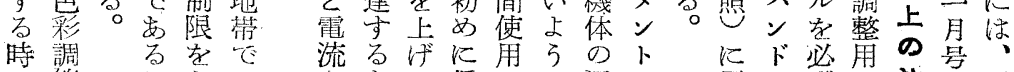
に節とらメををて低世に通は 子をい汗ッら行電ずす風温 め行 万るキるにき压にるに度 そ点の用と款を置。注が のてはで電:る長かい意上

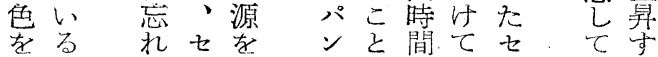

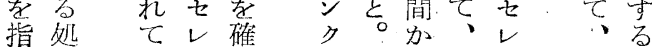
是灾度ン保

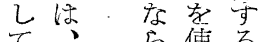
寸イ另以ン るキつ後を 物古便尔

周之: 纷 品化
置儿紫等

くを指切意

之, 定換

・ッの ス

卜子位 イ

ラと犆 ツ

ンノにチ スッ止孝 焼のめ揞 損中る尔 等間こる

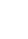

